\title{
The International Implications of October 1979: Toward a Long Boom on a Global Scale
}

John B. Taylor

】 am pleased and honored to be here to share my thoughts on the momentous event that occurred on October 6, 1979, and I thank Bill Poole, Bob Rasche, and Dan Thornton for being such gracious hosts. I will argue tonight that the masterful decisions made that day represented a critical first step in reasserting American leadership in economic policy around the world. This leadership, which continues today, has benefited not only the United States but also the entire international community. It has brought forth policies that have increased price stability, lessened fluctuations in output and employment, and promoted longer, more sustained economic expansions around the globe while restoring the dollar as a stable reserve currency.

Anyone who was more than just a casual observer of economic policymaking at the time realized that the measures announced on October 6 represented a major change in the conduct of monetary policy. If pursued to their conclusion, the measures would break the back of a vicious cycle of accelerating prices. If translated into new lasting principles of monetary policy, the specific measures would represent a true "regime" change. However, armed with monetary policy models that incorporated both inflation momentum and rational expectations, I also realized that tighter control of money was going to be associated with considerable economic strain for a period of timenot as bad or as long-lasting a strain as some pessimists had predicted, but a severe strain nonetheless. This would require exceptional fortitude by the Federal Reserve and broad support from elsewhere in the government.

\section{EVENTS PRECEDING OCTOBER 6, 1979}

It is difficult today to appreciate how desperate the economic situation had become 25 years ago. It is difficult because the United States has enjoyed a prolonged period-a long boom-of low inflation and long economic expansions since the early 1980s. But by 1979, inflation had moved up to a double-digit pace and threatened to spiral higher. The economy was showing signs of weakness, and many were predicting recession and rising unemployment. The mood in financial markets was becoming one of deep gloom, as the dollar was sinking and interest rates were soaring. Surveys showed that inflation expectations were climbing to unprecedented double-digit levels, and public opinion polls were consistently indicating that inflation was the number one worry.

Needless to say, confidence in U.S. macroeconomic management had been plunging both at home and abroad and had no doubt fallen to a post-World War II low. For its part, the Federal Reserve had been setting ranges for money growth that it thought to be consistent with bringing inflation down. However, it had been overshooting or pressing the upper limits of those ranges regularly. To many observers, the Fed's difficulty in keeping the monetary aggregates within the announced ranges were owed to its operating procedures, which involved actions to move the federal funds rate that were too little and too late, leaving the Fed behind the curve.

On August 6, 1979, a new Chairman of the Fed-Paul Volcker-took office. At first, the arrival of Volcker came as a relief to market participants. Through his public record and statements, Paul 
Volcker was seen to challenge the common wisdom of the time that inflation had favorable effects on employment. Instead, he believed that inflation was a corrosive force that undermined economic performance. His views were consistent with thennew advances in macroeconomics that pointed to the futility of trying to exploit an inflationunemployment trade-off, and perhaps he was influenced by such views. In any case, many market participants hoped that he would succeed in bringing inflation down. He was experienced, having served for four years as president of the New York Fed and five years as Under Secretary of the Treasury.

However, the confidence of market participants in Volcker's ability to lead the Fed on a disinflationary path was shaken on September 18. On that day the Federal Reserve Board approved a discount rate hike of 50 basis points to accompany a Federal Open Market Committee decision to tighten policy. But the vote, publicly announced, was very close-only four to three-and commentary that followed suggested that the chance of further tightening was all but gone. With money and prices accelerating, the situation looked bleak.

\section{OCTOBER 6, 1979}

What followed was one of the most masterful efforts in history by the head of a central bank to deal with a growing national and international problem. In the weeks after the September meeting, Paul Volcker put together a package that received the support of every member of the Board and every Reserve Bank president. It contained three key items: First, a full-percentage-point increase in the discount rate; that appealed to those believing the situation called for another traditional dose of monetary medicine. Second, a marginal reserve requirement on managed liabilities of large banks; that appealed to those who wanted to take action to restrain the surge in bank lending. And third, the new reserve-based operating procedures.

The new operating procedures allowed the Fed to say, with some legitimacy, that it was the market, and not the Fed, that was setting the level of the funds rate. The procedures also appealed to those who believed that a reserve-based operating procedure would result in more timely and sizable interest rate responses to inflation, which would help the Fed stay in front of rather than fall behind the inflationary curve. In retrospect, that may have been the most lasting feature of the October 1979 measures. The procedures also offered more two-way flexibility for prompt downward movements in the federal funds rate, which appealed to those who voted against the September 18 discount rate hike, fearing the economy was already sliding into recession.

\section{THE AFTERMATH OF OCTOBER 6, 1979}

The sustained monetary restraint called for by the operating procedures implied a protracted period of economic weakness. It called for a degree of fortitude by Chairman Volcker and his colleagues that had been highly atypical of central banks in the late 1960s and 1970s. This had to have been a very lonely and nerve-wracking period for the Federal Reserve. Stories abound about the daily mail deliveries of scraps of two-by-fours from the ailing construction sector with inscriptions begging for relief, and about angry farmers who circled the Fed building on Constitution Avenue, not to mention the countless letters protesting high interest rates.

Chairman Volcker and his colleagues were resolute for the next couple years, and their efforts, along with subsequent ongoing vigilance to prevent the economy from overheating, paid tremendous dividends for the United States. Core consumer price index inflation, which surpassed 11 percent in 1979, fell to under 5 percent in 1982. It has since been brought down further and held down under Chairman Alan Greenspan's leadership. With this, inflation expectations have marched down to very low levels, while public opinion polls have shown that inflation worries have moved completely off the radar screen.

\section{KNOWLEDGE AND LEADERSHIP}

The October 6 events and their immediate aftermath provide a wonderful case study on 
implementation of economic policy in practice. In my view, both knowledge and leadership are essential if one is to get the job done. Simply knowing the economic theory or proposing the economic reform is not enough. The Fed, under Chairman Paul Volcker, understood the true seriousness of the inflation problem. They and many others in academia and elsewhere understood the economic forces that were causing the rising inflation that had plagued the United States through much of the 1970s.

But implementing the solution required leadership and skillful coalition-building. As I have emphasized, the measures taken on October 6, 1979, were designed to receive wide support at the FOMC, and they got wide support. Implementation also required a high level of technical knowledge and good operational management within the Fed staff-especially given that the lagged reserve requirements in place at the time were not well suited for reserve-based monetary control. Moreover, implementation required staying the course for several years through very difficult times, and this is where support from elsewhere in the government-both the administration and Congress-was essential.

\section{INTERNATIONAL IMPACTS AND THE SPREAD OF KNOWLEDGE AND LEADERSHIP}

The United States was not the only country struggling with inflation in the late 1970s. Inflation had reached double digits in the United Kingdom, Italy, France, and Canada and was even high in Germany. The policy shift by the United States was followed by the United Kingdom, which adopted a monetary targeting framework in March 1980. ${ }^{1}$ Many of the other countries, however, held to the view that monetary policy was ineffective in controlling inflation and focused on incomes policies to restrict the growth of wages and prices. These differences in views were evident at the Executive Board of the International

\footnotetext{
1 Goodhart (2005) notes that the Bank of England was considering
} changing its operating procedures in 1979.
Monetary Fund. ${ }^{2}$ Over time, however, this shift in focus of monetary policy occurred in all the developed economies and also in many emerging market and developing economies.

To understand this diffusion of knowledge, note that two lasting monetary principles emerged from the specific monetary measures of October 6 , 1979, even though the measures themselves ended in 1982. It was these principles that spread around the world.

First is a commitment to price stability. A central bank needs to be committed to price stability, and this view is now widespread. Indeed, according to a recent survey of 94 central banks, 96 percent have price stability as a statutory goal. ${ }^{3}$ A milestone in this area occurred in 1989, when New Zealand adopted legislation that required the central bank, in consultation with the government, to set an inflation target, a change that was followed by other countries. By 1998, 54 central banks had set inflation targets. ${ }^{4}$

Second is the focus of central banks on more systematic and transparent procedures for setting the policy instruments in a way that will bring about the goal of price stability. Both theory and empirical studies indicate that monetary control is easier if monetary policy objectives are seen as credible, enabling economic agents to adjust their behavior to those objectives, and policy transparency has enhanced credibility. In comparing the pre- and post-October 1979 periods, one finds that monetary policy in the United States has become more responsive both to changes in inflation and changes in output. During the late 1960s and the 1970s, a 1-percentage-point rise in the rate of inflation resulted on average in a less than 1percentage-point rise in the federal funds rate. Since then, the federal funds rate has increased by more than 1 percentage point for every 1percentage-point rise in inflation. This difference is of fundamental importance. If the federal funds rate rises by less than the inflation rate, real

\footnotetext{
2 Boughton (2001).

3 Mahadeva and Sterne (2000).

4 Mahadeva and Sterne (2000).
} 


\section{Figure 1}

\section{Consumer Price Inflation (1970-2004)}

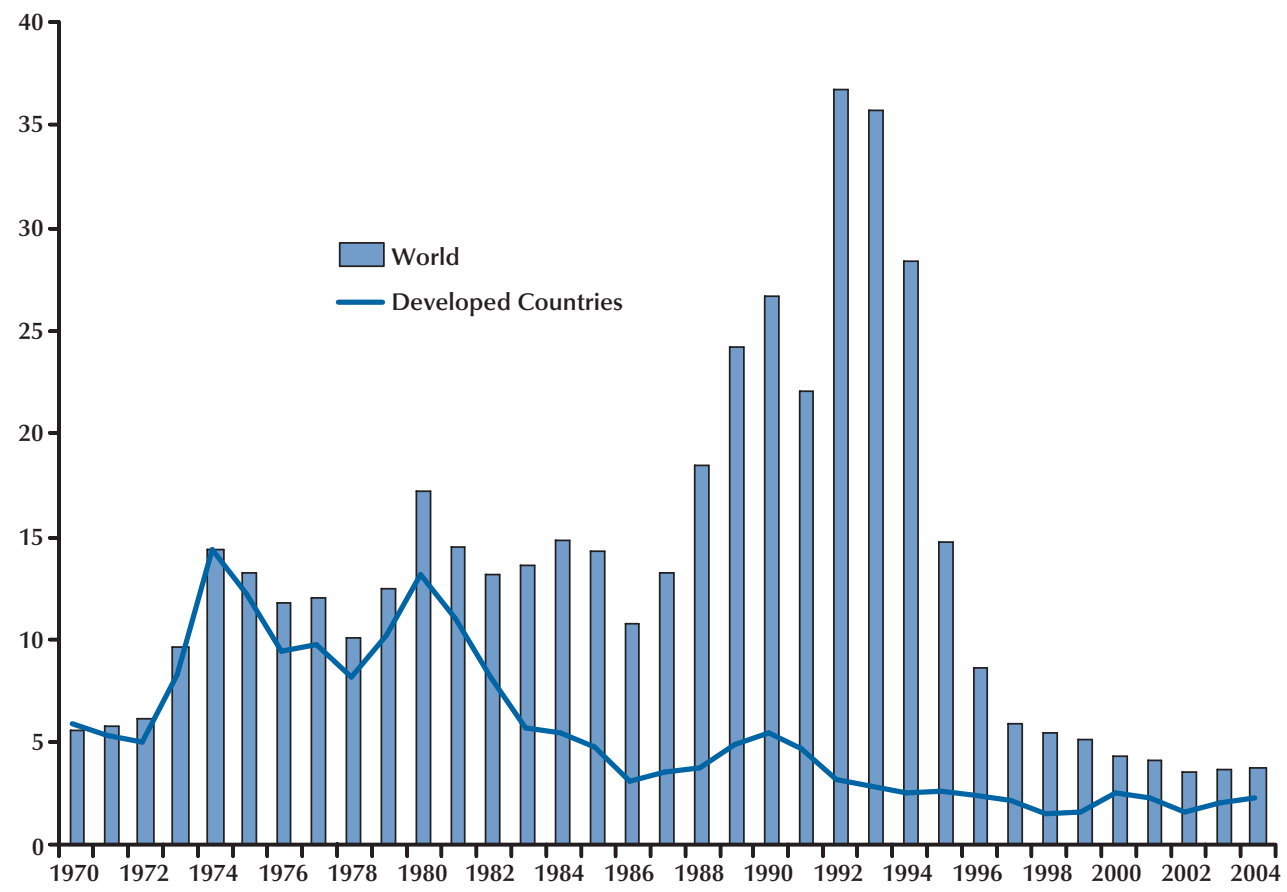

SOURCE: IMF, International Financial Statistics, and World Economic Outlook.

interest rates decline. It was this failure to focus on real interest rates that allowed inflation to accelerate in the 1970s. This greater responsiveness is not unique to the United States but also has been observed in other countries. ${ }^{5}$

The focus on price stability and on accompanying policy procedures has resulted in a sustained decline in inflation throughout the world (see Figure 1). The developed economies showed a declining trend after 1980. Inflation in these economies fell from an average of 13 percent in 1980 to 2 percent in 1997 and has remained close to 2 percent since then-tracking closely the experience in the United States.

Inflation in the emerging markets remained persistently high well after the drop in the developed economies. By the mid-1990s, however,

5 Clarida, Galí, and Gertler (1998). the changes in the monetary policy process had become more common throughout the world. The deceleration in inflation has been amazing. As recently as 1994, inflation in the emerging markets averaged 65 percent; over the past four years, in contrast, it has been around 6 percent.

As inflation has declined, so has its variability. In the developed economies, inflation variability, as measured by its standard deviation, fell from 3.4 percent in the 1980 s to 1.3 percent in the $1990 \mathrm{~s}$ and so far this decade is less than 1 percent. In the emerging markets the variability of inflation fell from 24 percent in the 1990s to less than 1 percent this decade. There is now little difference between the variability of inflation in the developed and emerging economies. This remarkable accomplishment is a direct result of the changes in the monetary policy process that began 25 years ago. 


\section{Figure 2}

\section{U.S. Real GDP (percent deviation from trend)}

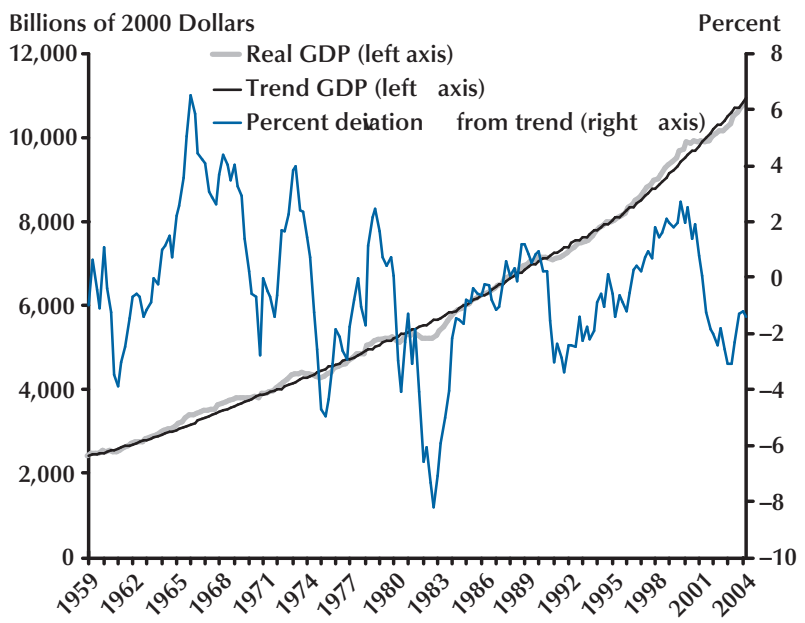

SOURCE: Bureau of Economic Analysis and the Congressional Budget Office.

\section{REDUCTION IN OUTPUT VOLATILITY AND THE LONG BOOM}

Impressive as these results are, they are only one part of a good story. At about the same time that the Fed was implementing the famous October 6 measures, I published a paper with an estimate of an efficiency frontier between the variability of inflation and output, noting that, with policy in place up until that time, the United States was off the frontier. ${ }^{6}$ Looking at the evidence, it is clear that since then we have either gotten closer to the frontier or that the frontier itself has shifted in a favorable direction. In other words, output variability has declined along with inflation variability.

In a Homer Jones Lecture I gave several years ago, I referred to this period of low output volatility in the United States as the "long boom" (see Figure 2). The "great moderation" is another term that has been used to describe the same phenomenon. Since 1955 there have been eight recessions, as determined by the National Bureau of Economic

6 Taylor (1979).

\section{Figure 3}

\section{United Kingdom Real GDP (percent deviation from trend)}

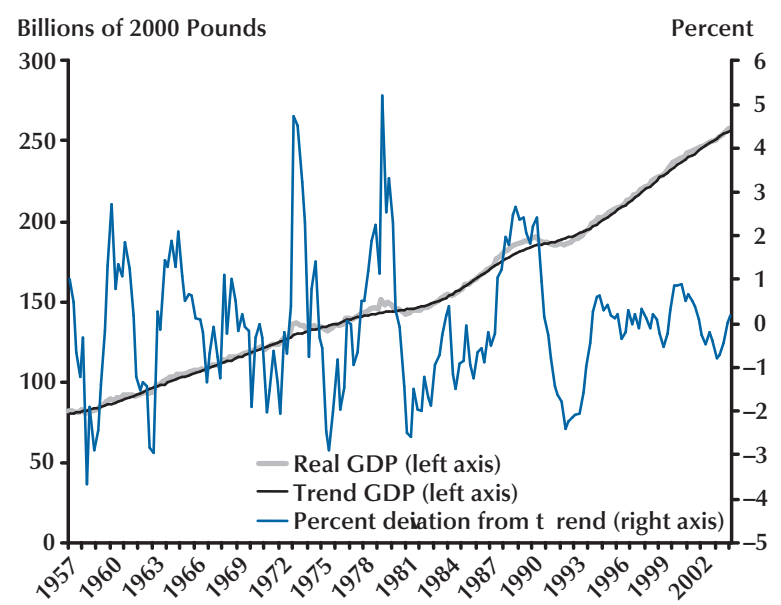

SOURCE: IMF, International Financial Statistics, and the U.S. Treasury.

Research (NBER). Two things stand out about the recent recessions. First, they were relatively mild. The average decline in output from peak to trough in the previous six recessions was 2.0 percent. Output in the 1990 recession declined by 1.3 percent. In 2001, output rose slightly (0.5 percent) from (the quarter of the) NBER peak to (the quarter of the) trough. Second, these two recessions were relatively short; both lasted less than eight months. The six previous recessions lasted slightly more than an average of 11 months. Equally important, the past two expansions were the longest peacetime expansions over the entire NBER measurement period that began in 1854. The most recent expansion lasted 120 months, surpassing by 14 months the expansion of the 1960s during the Vietnam War era.

The same phenomenon is found in other counties. In the developed economies as a whole the variability of the real gross domestic product (GDP) (measured as a deviation from trend) fell from 1.8 percent in the 1980 s to 1.0 percent in the 1990s and has remained steady since then. ${ }^{7}$ The

7 Trend output is calculated using a Hodrick-Prescott filter. 


\section{Figure 4}

\section{Chile Real GDP (percent deviation from trend)}

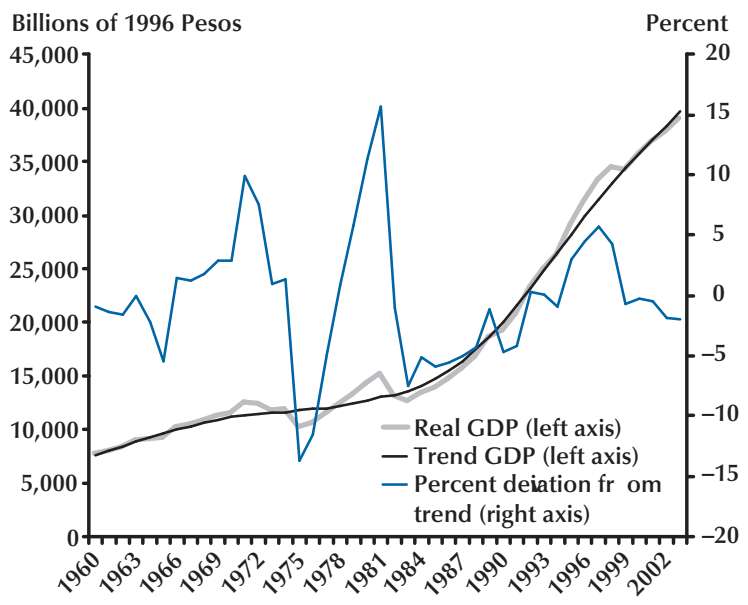

SOURCE: IMF, International Financial Statistics, and the U.S. Treasury.

experience of the United Kingdom (see Figure 3) is particularly impressive. Since 1992 the United Kingdom has not had a single quarter of negative output growth, as measured by the quarter-toquarter changes in real gross domestic product. Over the last $4 \frac{1}{1} 2$ years, output volatility has only been about 50 basis points.

In the emerging markets, the decline in inflation is still recent, but some emerging market economies have already seen a lowering of the variability of output. In Chile (see Figure 4), output variability declined by half in the 1990s. In Brazil (see Figure 5), output variability has begun to decline, too. I am optimistic that, given continued progress by the emerging markets in maintaining low and stable inflation, these economies will experience a longer boom over the course of this decade.

Several arguments are often cited for the improvement in the output-inflation variability frontier. According to the "good luck" argument, the number and magnitude of shocks hitting the world economy have declined. According to the "structural change" argument, supply shocks have a less pronounced effect on the economy as a result of changes in the structure of the economy.

\section{Figure 5}

\section{Brazil Real GDP (percent deviation from trend)}

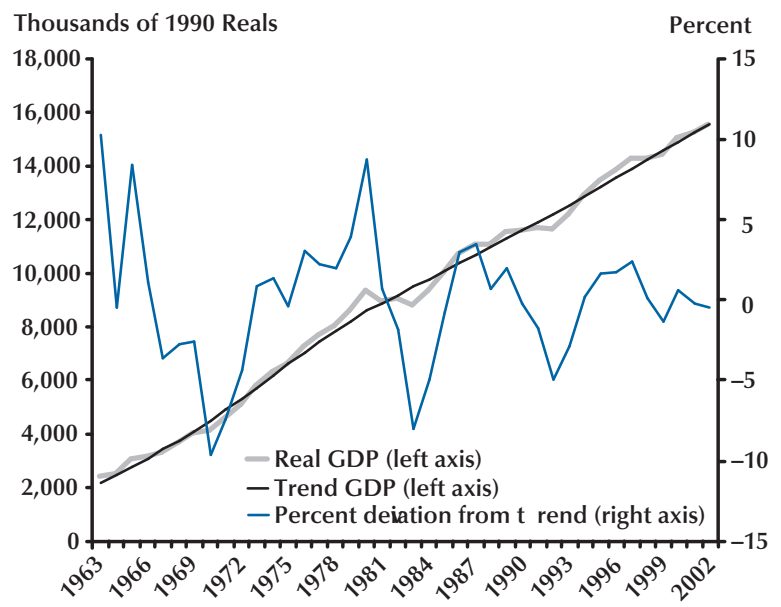

SOURCE: IMF, International Financial Statistics, and the U.S. Treasury.

Some changes often cited include an increase in the services sector's share in the economy and improvements in inventory management.

I prefer a policy explanation closely connected to the monetary policy changes that began in October 1979. Reducing substantially the boombust cycle has been an important contributor. Recessions in the postwar period typically have been preceded by rises in the rate of inflation. Thus, by keeping inflation low, monetary policy has reduced the likelihood of recessions. Moreover, ending inflation and keeping inflation expectations low has given central banks the credibility to address adverse supply shocks. In the past, in the face of an oil price shock, central bankers were faced with the vexing choice of whether to cushion the loss in output or resist the upward pressure on prices. If they pursued the former, they risked dealing with higher and more entrenched inflation expectations. In contrast, around the globe today, people have become more confident that central banks are not going to allow such shocks to feed into more long-term inflation. As a result, central banks can respond more to the output and employment effects. 
It is informative to contrast the discussion of policy responses to the recent run-up in oil prices with discussions that took place in the early 1990s. At that earlier time, there was the widespread view that central banks had to steer a narrow course and provide resistance to the price-level effects of the shock so as to avoid reigniting inflation expectations. Today, the anti-inflation credibility earned over the past couple decades has served to anchor inflation expectations and give central banks more leeway to cushion the output effects.

\section{CONCLUSION}

In sum, reflection on the international implications of the momentous event of October 1979 in the United States reveals powerful lessons. I am convinced that the hard-fought gains from new policies that began to be adopted then will continue to pay large dividends in the future. As long as monetary policymakers retain the lessons learned, the long boom that more and more countries are experiencing around the world will be sustainable at a global scale. By remaining vigilant against inflation, central bankers will be able to keep inflation expectations low, giving them more scope to counter shocks. And the more stable economic and financial environment will foster more productivity-enhancing business decisions.

I am optimistic that policymakers in emerging markets and developing countries are learning these lessons as well. Given the hyperinflation and economic instability these countries have experienced in the past, the rewards from better policy are huge. During the past few years, I have worked closely with policymakers in many countries. We have consistently supported these leaders as they implement policies that promote price stability and transparent systematic procedures for adjusting policy instruments. I am convinced these principles will bring substantial long-term benefits to this part of the world, too.

\section{REFERENCES}

Boughton, James. Silent Revolution: The International Monetary Fund 1979-1989. Washington, DC: International Monetary Fund, 2001.

Clarida, Richard; Galí, Jordi and Gertler, Mark. "Monetary Policy Rules in Practice: Some International Evidence." European Economic Review, 1998, 42(6), pp. 1033-67.

Goodhart, Charles A.E. "Panel Discussion II: Safeguarding Good Policy Practice.” Federal Reserve Bank of St. Louis Review, March/April 2005, 87(2, Part 2), pp. 298-302.

Mahadeva, Lavan and Sterne, Gabriel. Monetary Frameworks in a Global Context. New York: Routledge, 2000.

Taylor, John B. "Estimation and Control of a Macroeconomic Model with Rational Expectations." Econometrica, September 1979, 47(5), pp. 1267-86. 
